\title{
CROSS-NATIONAL EVIDENCE ON THE BURDEN OF AGE-RELATED PUBLIC TRANSFERS AND HEALTH BENEFITS
}

\author{
Gary Burtless \\ CRR WP 2006-6 \\ Released: February 2006 \\ Draft Submitted: December 2005 \\ Center for Retirement Research at Boston College \\ 550 Fulton Hall \\ 140 Commonwealth Ave. \\ Chestnut Hill, MA 02467 \\ Tel: 617-552-1762 Fax: 617-552-0191 \\ http://www.bc.edu/crr
}

\begin{abstract}
*Gary Burtless is a John C. and Nancy D. Whitehead Chair in Economic Studies at The Brookings Institution. This paper follows up earlier research presented in "The Age Profile of Income and the Burden of Unfunded Transfers in Four Countries: Evidence from the Luxembourg Income Study," Center for Retirement Research Working Paper 2005-01 (Chestnut Hill, MA: Boston College, January 2005). I gratefully acknowledge the excellent research assistance provided by Dan Theisen of Brookings and productive collaboration with LIS staff in Luxembourg. The research reported herein was performed, in part, pursuant to a grant from the U.S. Social Security Administration (SSA) funded as part of the Retirement Research Consortium. The findings and conclusions expressed are solely those of the author and do not represent the views of SSA, any agency of the Federal Government, Boston College or The Brookings Institution.

(C) 2006, by Gary Burtless. All rights reserved. Short sections of text, not to exceed two paragraphs, may be quoted without explicit permission provided that full credit, including $(\mathcal{C}$ notice, is given to the source.
\end{abstract}




\section{About the Center for Retirement Research}

The Center for Retirement Research at Boston College, part of a consortium that includes a parallel centers at the University of Michigan and the National Bureau of Economic Research, was established in 1998 through a grant from the Social Security Administration. The goals of the Center are to promote research on retirement issues, to transmit new findings to the policy community and the public, to help train new scholars, and to broaden access to valuable data sources. Through these initiatives, the Center hopes to forge a strong link between the academic and policy communities around an issue of critical importance to the nation's future.

\section{Center for Retirement Research at Boston College \\ 550 Fulton Hall \\ 140 Commonwealth Ave. \\ Chestnut Hill, MA 02467 \\ phone: 617-552-1762 fax: 617-552-0191 \\ e-mail: crr@bc.edu \\ http://www.bc.edu/crr}

\section{Affiliated Institutions:}

American Enterprise Institute

The Brookings Institution

Center for Strategic and International Studies

Massachusetts Institute of Technology

Syracuse University

Urban Institute 


\begin{abstract}
This paper uses micro-census income data from the Luxembourg Income Study (LIS) and the Medical Expenditure Panel Survey (MEPS) in combination with previously published data on the age profile of public health spending to measure the current and future burden of financing public transfers, particularly benefits supporting the aged and near-aged. The burden of unfunded transfers is defined as the tax on factor income that is needed to finance paygo transfers under a balanced budget rule. I develop a framework for estimating and forecasting this burden using micro-census reports on the current age distribution of factor incomes, the age distribution of transfer incomes, and projections of the future age structure of the population. I adjust micro-census income reports to reflect under-reporting in household surveys. In an extension of previous research, I develop new estimates of public health benefits by age of recipient. Estimates of current and future tax burdens are derived for four OECD countries. These show that the burden of U.S. transfers is unusually sensitive to the effects of an aging population. In contrast, transfers in Finland and the United Kingdom are less heavily tilted toward aged beneficiaries. Factor incomes received by aged Americans are high by international standards, providing a partial offset to the sharp tilt of U.S. transfers in favor of the elderly. A major surprise is the relatively high disposable incomes of aged citizens in Germany and the U.S. When the full cost of public health benefits is added to other sources of cash and near cash income, the aged in those countries receive effective incomes that are approximately as high as adults who are near the peak of their working careers.
\end{abstract}




\section{Introduction}

The burden of population aging depends crucially on the relative sizes of the aged and working-age populations, the relative consumption of aged and working-age households, and the income sources used to pay for old-age consumption. To the extent that elderly households depend on transfers financed out of the current incomes of working-age families, the trend toward an older population can impose heavy financial burdens on active workers. If aged households pay for their current consumption largely out of their own current earnings or past savings, however, the extra burden associated with population aging may be modest.

Much of the cross-national analysis of the potential burden of aging populations focuses on prospective changes in the ratio of retired to working-age populations, that is, the old-age dependency ratio. Less attention has been directed toward measuring cross-national differences in the actual support that aged households derive from working-age households. This paper examines international differences in sources of support for old-age consumption. How much consumption is financed with aged households' own earnings and saving? How much depends on transfers from the working-age population?

Aged households in all industrialized countries derive a large fraction of their incomes from public pensions and government transfers, but countries differ widely in the proportion of old-age income that is provided through public budgets. Older people in the United States obtain a smaller percentage of their cash retirement income from transfers and a larger percentage from private income sources, including property income, employer-sponsored pensions, and labor earnings. In a sample of 10 OECD countries, for example, analysts found that the United States ranks second in the percentage of total elderly household income derived from earnings, third in the percentage derived from property and financial assets, and ninth in the percentage derived from government transfers, including public pensions (Rein and Stapf-Finé 2001). Because a large fraction of older Americans own the homes they live in, they also receive a sizeable flow of private housing services that is not reflected in their money income reports.

This paper distinguishes among three basic kinds of financing for old-age consumption:

- Transfers from the public budget, including cash and near-cash transfers and government health insurance benefits;

- Own earnings of aged households; and 
- Income from savings (including the service flows from home ownership).

Following procedures developed in an earlier paper on this topic, I use micro-census information on income for four countries to derive comparable statistics on the share of old-age income that is derived from net transfers and from aged households' own current earnings and past savings (Burtless 2005). As a check on these calculations, I determine whether the microcensus reports of income can be reconciled with aggregate national statistics on income flows, and I make adjustments in the micro-census tabulations to reflect the shortfall in income reported in household surveys. In a major extension of the earlier research, I also impute net health transfers received by individuals through public institutions and government-financed health insurance. Every industrialized country provides health insurance protection to some or all of its citizens. The insurance is much more valuable to the aged than to the non-aged, because elderly citizens consume much more health care than the non-elderly. The gap in the value of the public benefits is particularly important in the United States, which provides nearly universal health insurance only to its aged population. A much smaller percentage of the non-aged population receives net transfers under the U.S. system. Consequently, the age profile of public health benefits is sharply upward sloping in the United States.

The remainder of the paper is organized as follows. The next section proposes a simple framework for measuring the effects of the population age distribution, the age distribution of factor income, and the age profile of pay-as-you-go (paygo) government transfer benefits on the tax burden faced by the economically active population. The framework is a natural extension and generalization of the old-age dependency ratio, a popular though misleading measure of the burden imposed by an aging population. The following section briefly describes the microcensus survey data on income and health care consumption needed to measure household incomes. It describes procedures to allocate individual-level incomes between components derived from own earnings and savings, on the one hand, and paygo transfers, on the other. Procedures are also developed to adjust reported incomes so that the implied aggregate income and publicly financed health care consumption are consistent with estimates in the national income and product accounts and recorded in the OECD social expenditures data base. The next section describes empirical estimates of the age profiles of factor incomes and of paygo transfer incomes in four OECD countries. The results from that section are used in the following section to develop new estimates of the tax on factor income that is needed to finance paygo transfers 
over the next half century. My estimates suggest that a generous social welfare system does not necessarily generate steep increases in the tax burden as the population grows older, whereas less generous social welfare systems may generate steep increases in required tax rates depending on the age profile of factor incomes and of government benefit generosity.

\section{Old-age dependency burden}

A common way to measure the burden imposed by the aged on the working age population is to calculate the ratio of old to the number of working age adults. Under stylized assumptions regarding the pension formula and work patterns among the young and the old, the trend in the old-age dependency ratio will parallel the trend in the payroll tax rate needed to finance retirement benefits. In a pay-as-you-go pension program, the taxes imposed on current wage earnings are just sufficient to pay for benefits provided to the retired population. Assuming all aged adults receive a pension and all working-age adults are employed, a balanced-budget rule in the pension program requires that current benefit payments must equal tax revenues:

(1) $\quad \mathrm{P} a_{2}=\tau \mathrm{W} a_{1}$

where $\mathrm{P}=$ Average pension benefit;

$\mathrm{W}=$ Average wage;

$\tau=$ Tax on wages;

$a_{1}=$ Proportion of population that is working age; and

$a_{2}=$ Proportion of population that is aged.

(2) $\tau=\frac{\mathrm{P}}{\mathrm{W}} \underline{a}_{2}$

If a pension formula sets the average benefit payment so that it is a fixed percentage of the average wage, the paygo tax rate, $\tau$, needed to support the pension program will vary over time in proportion to the old-age dependency ratio, $a_{2} / a_{1}$. An increasing share of the aged in the population will inevitably boost the percentage of earnings that must be set aside to pay for benefits to the elderly.

Government transfers and other public spending are not provided only to the old. Many children and working-age adults also derive support from government transfers. Nor are the taxes used to pay for transfers imposed solely on wages. Means-tested government transfers and most public health insurance benefits are financed out of general government revenues, which 
are derived from taxes on personal income, property, and consumption as well as on labor earnings.

If transfers are financed with a proportional tax on all factor income, the balanced-budget tax rate needed to pay for age-related transfers can be expressed as

$$
\tau=\frac{\mathrm{P}_{T O T}}{\mathrm{~W}_{T O T}+\mathrm{R}_{T O T}}=\frac{\sum a_{i} \mathrm{P}_{i}}{\sum a_{i}\left(\mathrm{~W}_{i}+\mathrm{R}_{i}\right)}
$$

where $\mathrm{P}_{i}=$ Average transfer benefit received by persons in age group $i$;

$\mathrm{W}_{i}=$ Average labor income earned by persons in age group $i$;

$\mathrm{R}_{i}=$ Average capital income earned by persons in age group $i$;

$\tau=$ Tax rate on total factor income, $\mathrm{F}_{T O T}=\mathrm{W}_{T O T}+\mathrm{R}_{T O T}$;

$a_{i}=$ Proportion of population in age group $i$.

Note that an age group's average factor income, $\mathrm{F}_{i}$, is simply the sum of its average wage income, $\mathrm{W}_{i}$, and average capital income, $\mathrm{R}_{i}$. It is convenient to express the age profile of factor income by reference to the mean factor income received by the age group that receives the highest factor income, say, $\mathrm{F}_{M} . M$ can be interpreted to mean "middle aged," since income from earnings and capital usually reach a peak when people attain middle age. If there are $N$ age groups and we define $f_{i}=\mathrm{F}_{i} / \mathrm{F}_{M}$, then the age profile of factor income is indicated by the sequence $f_{1}, f_{2}, f_{3}, \ldots, f_{M}, \ldots, f_{N}$, where each $f_{i}$ is the mean factor income in group $i$ expressed as a fraction of the factor income received by a middle-aged person, and $f_{M}=1$. Suppose that the average transfer benefit paid to a particular age group $i$ is also measured relative to the mean factor income received by a middle-aged person. If $\beta_{i}=\mathrm{P}_{i} / \mathrm{F}_{M}$, we can re-write equation (3) as

$$
\tau=\frac{\sum a_{i} \underline{\mathrm{P}}_{i}}{\sum a_{i} \mathrm{~F}_{i}}=\frac{\sum a_{i} \underline{\beta}_{i} \underline{\mathrm{F}}_{M}}{\sum a_{i} f_{i} \mathrm{~F}_{M}}=\frac{\sum a_{i} \underline{\beta}_{i}}{\sum a_{i} f_{i}} .
$$

The paygo tax rate needed to support the transfer system is therefore a function of the age distribution of the population, $a_{1}, a_{2}, a_{3}, \ldots, a_{N}$, the age profile of factor income, $f_{1}, f_{2}$, $f_{3}, \ldots, f_{N}$, and the relative generosity of transfer payments compared to average factor income of the middle-aged, $\beta_{1}, \beta_{2}, \beta_{3}, \ldots, \beta_{N}$. If the age distribution is skewed toward groups with low benefit payments and high factor incomes, the tax needed to finance paygo transfers will be 
low. As a graying population increases the proportion of people with high benefit requirements and low factor incomes, $\tau$ must rise.

\section{Measuring income}

This paper uses several data sources to measure the incomes and public health benefits received by different age groups in the population. In the first phase of the research, described in detail in an earlier paper, I used micro-census data from the Luxembourg Income Study (LIS) to approximate the capital and labor incomes and the cash and near-cash transfer incomes received by people classified according to age. I then adjusted the data to assure that aggregate income corresponded with incomes recorded in the national income and product accounts (NIPA) (Burtless 2005). A crucial extension of the earlier research is to provide estimates of the public health insurance benefits obtained by each age group in the population. Public health benefits are not recorded in the LIS household survey files or by most other household surveys. Although many people know whether they are insured under a public or private health insurance program, few are capable of estimating the amount of reimbursement that is provided for their health care by an insurance program. The U.S. Census Bureau imputes the value of health insurance protection to respondents in its annual income and demographic survey, but the estimates are not finely calibrated to reflect respondents' ages. Moreover, no imputations are made when respondents fail to report they or other family members are covered by an insurance plan. Consequently, the U.S. survey misses a large portion of the health insurance provided under Medicare and Medicaid and fails to provide an accurate age profile of publicly subsidized health spending. In this paper I use detailed estimates made by the European Union and develop new estimates for the United States of the age profile of public spending on health insurance and health care. These estimates are then adjusted to reflect aggregate public expenditures on health social expenditures developed by the OECD.

In combination, the tabulations just described can provide estimates of the benefit ratios, $\beta_{i}$, and age profiles of factor incomes, $f_{i}$, needed to calculate $\tau$. The time trend in tax burdens can then be computed using demographic projections of the future population age structure. If the age profile estimates were accurate and complete, they would provide a reliable guide for estimating the current tax on factor incomes needed to support paygo transfers. Their usefulness for predicting future tax burdens is more problematical, since future benefit ratios, $\beta_{i}$, and factor 
income profiles, $f_{i}$, will almost certainly change as a result of population aging. Nonetheless, the projected values of $\tau$ offer a starting point for assessing a country's potential burden assuming that its economic and political institutions remain unchanged.

Micro-census data suffer from a number of shortcomings that make them inaccurate or incomplete. In most countries data on family income are collected in household interviews conducted by a national census agency or some other survey organization. In only a handful of countries are the data obtained from administrative records of the tax collection or social security agency. In countries that rely on household interviews, some respondents do not agree to be interviewed. Others fail to answer all the questions posed by an interviewer or supply inaccurate information. Equally important, the survey questions do not provide a complete tally of relevant household income. Some elements of employer compensation and self-employment income are not covered by the questionnaire. A large percentage of capital income is missed by most household surveys. Respondents may not be asked about their share of investment earnings in insurance or pension programs in which they participate. Few household surveys elicit enough information about consumer durables or owner-occupied homes to allow researchers to calculate accurately the value of capital services that owners derive from property they own. I make adjustments in the survey responses to increase the reported income amounts up to known totals reflected in a country's NIPA. These adjustments are much more important for some income sources, such as self-employment earnings and property income, than they are for others. Moreover, under-reporting in household surveys is a more serious problem in some countries than others. After household survey data are adjusted to reproduce income totals shown in each country's NIPA, the estimates of $\tau$ will be more comparable from one country to the next.

As noted above, the difficulty of accurately measuring public subsidies for health insurance and medical care consumption is even more formidable than the problem of ascertaining a household's cash income. To obtain this kind of information, the U.S. Department of Health and Human Services sponsors the Medical Expenditure Panel Survey (MEPS), a combined household and administrative record survey that gathers detailed information on individual health care use, spending, and sources of health care payment for Americans who live outside of institutions. Because the MEPS data are compiled on an individual basis, they can be used to estimate health care utilization and sources of payment by age (Keehan et al. 2004). For a variety of reasons, including incomplete coverage of the population and personal health 
spending, the MEPS survey does not collect information on all publicly subsidized medical spending in the United States. Nonetheless, for the population and spending items covered by the survey, the aggregate spending amounts recorded in the MEPS correspond remarkably well to the totals estimated in the U.S. national health accounts (see Selden et al. 2001). In order to measure the age profile of overall health spending and publicly financed health spending for calendar year 2000, I performed tabulations of the MEPS Household Component Data, Full Year Consolidated Data File, for calendar years 1999-2001. ${ }^{1}$ The estimates from the MEPS sample are adjusted so that aggregate public spending on personal health care corresponds with estimates of U.S. public spending for that function reported in the OECD Social Expenditures database (OECD 2004b). The European Union has compiled similar estimates of the age profile of public spending on health care for a number of its member countries (Economic Policy Committee, European Commission 2001). An analyst can easily adjust the estimates so that aggregate public health benefits spending in an EU-member country corresponds to estimates in the OECD Social Expenditures database.

Cash and near-cash income sources. This paper examines 1999-2000 income patterns in four countries participating the Luxembourg Income Study (LIS): Finland, Germany, the United Kingdom, and the United States. These were the only four LIS countries that provided recent income data of sufficient breadth and accuracy so that I could reliably calculate tax burdens. To estimate the critical parameters in equation 4 , it is necessary to measure income separately within age groups and to distinguish between income derived from factor income and paygo transfers. The distinction between factor income and paygo transfers is not the same as the usual distinction between income derived from public and private sources. Retirement income that is obtained from a funded pension system, whether the funds are managed in the public or private sectors, represents factor income. The LIS provides detailed information about a variety of public and private income sources. In most cases it is straightforward to distinguish between income sources that represent factor income and those representing paygo transfers. Wage and salary income and most employer supplements to wages and salary represent a return for labor services. I classify self-employment income as labor income, though entrepreneurs' income

\footnotetext{
${ }^{1}$ I performed tabulations for three calendar years, 1999-2001, rather than for 2000 alone in order to reduce the sampling variability of estimated health care spending in narrow age groups. Health spending is highly skew, and consequently estimates of average health spending in small samples are quite imprecise (Burtless and Siegel 2004).
} 
partly reflects a return on capital. Means-tested benefits and public pensions from unfunded public programs, including the U.S. and German social security systems, the U.K. basic state pension, and the Finnish flat-rate pension scheme, clearly represent varieties of paygo transfers. In contrast, occupational pensions in Germany, the United Kingdom, and the United States are classified as factor income. This classification seems justified for the United States, even in the case of occupational pensions offered by public employers, because the private and public employer-sponsored pension programs are overwhelmingly capital funded (Bosworth and Burtless 2004). Finland's occupational pension system represents a hybrid or partially funded program. I classify one-quarter of Finnish occupational pensions as factor income and threequarters as paygo transfers.

It would be desirable to measure all income paid to an individual household (or to its agents) that represents returns on capital or labor services. The total should include all compensation paid in behalf of a wage and salary worker, including money and in-kind supplements to ordinary money wages as well as the compulsory taxes or contributions employers are obliged to pay for public social insurance. Supplements to wage income include voluntary and compulsory contributions for occupational pensions and for health, injury, and life insurance. Unfortunately, very few workers can accurately estimate how much their employers pay for these earnings supplements, so the LIS wage data usually reflect gross money wages before subtractions for the employee's own tax payments and social insurance contributions.

In addition to reported interest, dividends, and rental income, capital returns should include the investment income earned on insurance company and pension fund reserves held in behalf of individual survey respondents. Not surprisingly, few respondents know the value of these income items, so they are not reflected in the LIS data file. The capital income of a homeowner should include all or part of the flow of housing services that the owner derives from ownership of a home. In the case of Finland, Germany, and the United States, the LIS files include estimates of the return that homeowners derive as a result of ownership of a house. Unfortunately, the imputations are based on different procedures in different countries. In Finland and Germany the estimates reflect an assessment of the rental income a homeowner would receive if his or her home were rented in the private market. In the United States, the U.S. Census Bureau imputes equivalent rental income based on the assumed financial return that homeowners could earn on the net equity they hold in their homes (that is, the difference 
between the market value of their home and the balance on their home mortgage). I was able to make an imputation of rental income for U.K. homeowners based on the same procedure used by the U.S. Census Bureau.

Having classified the income items in categories corresponding to labor returns, capital returns, and pay-as-you-go transfers, the next step is to allocate income items to individuals based on their age. Income items representing the great majority of total income, including wages and salaries, self-employment earnings, and occupational pensions, are reported in LIS files on an individual basis. Other income sources, including many forms of property income and some paygo transfers, are only reported at the household level. Income items reported at the household level were divided equally between the household head and his or her spouse. When a household is headed by a single person, the head is assumed to be the sole recipient of all household income items. If more than one generation of adults lives in the same residence, this procedure can produce a misallocation of some household income items. Since there are comparatively few households containing two generations of adults, it seems unlikely the misallocation will be sizeable.

Table 1 shows estimates of factor incomes and paygo transfers in 1999 or 2000 for the four countries included in the study. The income totals reported in rows $1,3,5,7$, and 8 are estimates derived from the LIS files. They were obtained by multiplying LIS respondents' income reports by the population weights implied by the U.S. Census Bureau's International Data Base and then summing to find implied income totals. ${ }^{2}$ Lines 2, 4, and 6 show equivalent national income totals derived from the OECD National Accounts data base. A comparison of lines 1 and 2, for example, allows us to see how much of the aggregate employee compensation recorded in the NIPA is reflected in LIS wage and salary reports. The difference between the aggregate totals does not necessarily reflect income under-reporting in the LIS file. As noted

${ }^{2}$ The LIS data files cover 1999 incomes in the United Kingdom and 2000 incomes in Finland, Germany, and the United States. The average income estimates for individuals in each age category were summed to produce estimates of aggregate income using population cell weights for the relevant year implied by the International Data Base (U.S. Census Bureau 2004). In the earlier paper, I estimated aggregate income by using LIS-supplied sample weights (Burtless 2005). For a variety of reasons, those weights differ from weights implied by population estimates of the Census Bureau and other national and international statistical agencies. On average, the LIS weights yield national population estimates that are about $3 \frac{1}{2}$ percent smaller than those indicated in the Census Bureau's IDB. Since this paper uses different population weights than the earlier paper, the aggregate incomes differ from those shown in the earlier paper as well. 
above, employee compensation includes employer social contributions and supplements to wages that are not reflected in the money wages received by employees.

Rows $a, b, c$, and $d$ in the lower panel of Table 1 provide direct comparisons between LIS factor income items and equivalent items in the NIPA. Wages and salaries reported in LIS represent 79 percent to 83 percent of the compensation recorded in NIPA. This implies that 21 percent to 17 percent of factor income derived from wage and salary employment is missed in the LIS files. The percentage of aggregate income missing in the LIS is often much bigger for other income items. Moreover, the percentage of missing income varies across countries. Selfemployment income appears to be very well reported in Finland and the United Kingdom, but it is subject to greater under-reporting in Germany and the United States. The lower panel also shows wide national differences between capital income flows reported in the household surveys and the NIPA. Obviously, any adjustment of the LIS capital income reports to bring them closer to the aggregate income flows in the NIPA will substantially boost the measured incomes of capital owners in Germany and the United States.

Government health benefits. Any realistic measure of paygo transfers ought to include benefits provided in the form of public health insurance, but as noted above the LIS microcensus files do not include imputations of health insurance transfers for households in the European countries whereas such imputations are available for U.S. respondents. Health insurance transfers are obviously significant in all four countries. Public spending on health in 2000 was 5.0 percent of GDP in Finland, 5.8 percent in the United States, 5.9 percent in the United Kingdom, and 8.3 percent of GDP in Germany (OECD 2004a). ${ }^{3}$ Most public spending on health care consists of payments to support medical insurance for individuals. Since the cost of providing health care and the value of insurance transfers rises steeply with age in all developed countries, government transfers will be more heavily tilted toward the aged when public health insurance is included than when it is excluded (Cutler and Sheiner 2001 and Sheiner 2004).

To supplement the LIS data on cash and near-cash government transfers, I derived estimates of the age profile of publicly financed personal health care spending in each of the four

\footnotetext{
${ }^{3}$ This excludes public spending on health insurance premiums for government employees. Such premiums are part of employee compensation and are properly treated as part of employee compensation, that is, as a component of factor income.
} 
countries. The European Commission has published estimates of the age profile of public health spending in many member countries as part of long-term budget forecasting exercise (Economic Policy Committee, European Commission 2001, 33-36). The Commission's estimates show per capita public expenditures on health care, by year of age, measured as a percentage of each country's GDP per person. The estimates are based on detailed tabulations supplied by national governments for spending in 1998 (for the United Kingdom) or 2000 (for Finland and Germany). For a variety of reasons, the Commission's estimates are lower than seems consistent with the OECD's estimates of aggregate public expenditure on health care benefits (OECD 2004b). For example, the OECD Social Expenditures database shows that public spending on health benefits amounted to 5.0 percent of Finland's GDP in 2000. The European Commission's estimates of the age profile of public health benefits imply that such spending was only 4.6 of Finnish GDP. The discrepancy differs across the three European countries. In Germany, the European Commission's age profile estimates imply that public spending on health benefits accounted for 5.5 percent of German GDP. The OECD Social Expenditures database shows that aggregate spending on such benefits was 7.9 percent of GDP.

An even larger discrepancy arises in the United States. The MEPS file shows that public spending per person for health care expenses was slightly more than $\$ 900$, whereas the OECD Social Expenditures database implies that average public spending was about $\$ 2,000$ per person. The discrepancy can largely be explained by the restricted population coverage of the MEPS sample and exclusions in the spending items covered in the MEPS (Selden et al. 2001). Even if the discrepancies can be explained, however, the shortfall in aggregate spending means that the public health spending tabulated in the MEPS excludes a large fraction of public expenditures on health goods and services and insurance. If the excluded portion of the population is largely drawn from the high-spending elderly, or if omitted expenditure items are disproportionately consumed by a particular age group, the age profile measured in the MEPS may be misleading.

In spite of the limitations of the MEPS and the European Commission estimates, both sets of estimates can be used to form an estimate of relative public spending on people of different ages. This information can be combined with the OECD estimate of aggregate public spending on health benefits to form estimates of the age profile of public health benefits. Figure 1 displays estimates based on these calculations for Finland, Germany, the United Kingdom, and the United States. All four countries show a similar basic profile. Spending per person is low at 
younger ages and rises gradually or, in the case of the United States, steeply with age. In all four countries, per capita spending is several times larger for persons 75 and older compared with spending on people under age 55. The multiple is especially large in the United States, where public health insurance is available to only a minority of the population under 65 but almost the entire population 65 and older. Figure 2 shows estimates of the percentage of total U.S. health expenditures at each age that is publicly financed. In the population under age 65 , except in the youngest age group, less than 30 percent of total health expenditures is financed with government transfers or direct services. Among the U.S. population 70 and older, more than two-thirds of spending is paid for or directly supplied by the government.

Total income and public health benefits. The results for cash and near-cash transfers and for publicly funded health care goods and services can be combined and compared to OECD estimates of public social expenditures in the four countries. By definition, the public health care spending assigned to each age group sums to the total public spending on health benefits reported in OECD's Social Expenditures database. When these imputations are added to LISderived estimates of cash and near-cash transfers, we have an estimate of total paygo government transfers to households. Rows 8, 9, and 10 in Table 1 show these estimates. Row 11 in the table shows the OECD estimate of total public outlays on cash and near-cash transfer payments and government-financed health benefits. The bottom row in the lower panel of Table 1 shows the percentage of OECD-estimated government transfer payments that is reflected in the LIS files or imputed to the files as estimated public spending on health benefits. For both Finland and Germany reported and imputed transfer incomes in the aggregate are essentially identical to the amounts shown in the OECD database. In the United Kingdom and the United States there is a modest shortfall of reported and imputed government benefits. Part of the reason for the difference between LIS income reports and the OECD estimates of cash and nearcash benefits is the difficulty of obtaining accurate information about some government transfers, especially means-tested benefits (U.S. Census Bureau 1993, Appendix C).

Adjustment for under-reporting. The aggregate incomes reported in the LIS income files are smaller than corresponding income totals shown in the NIPA or the OECD Social Expenditures database (see Table 1). Since the shortfall in aggregate income differs across countries and across different types of income, it is essential to check the LIS estimates using income totals adjusted to reflect under-reporting in the household surveys. To perform this 
check I assume that under-reporting represents a constant proportional share of income across all age groups, while the proportional amount of under-reporting differs across different types of income. Most of the data needed to make this adjustment for under-reporting are displayed in Table 1.

The adjustment for under-reporting of wage and salary compensation, for example, can be performed using information in rows 1 and 2 of the table. Row 1 shows aggregate wage and salary income reported in the LIS data file, and row 2 shows total compensation, including wage supplements and mandatory contributions for social insurance, reported in the NIPA. To compensate for the LIS income shortfall, I multiply LIS wage and salary income amounts by the ratio of the entries in row 2 and row 1. For example, just 79 percent of the compensation paid to wage and salary workers in Finland is recorded as wage and salary income in Finland's LIS file. By increasing LIS-reported wage and salary income by 27 percent, the adjusted total wage and salary income in the LIS file would exactly match the wage and salary compensation reported in the NIPA. This procedure is used to adjust LIS labor income, most income from capital, and cash and near-cash transfer income. (The adjustment to cash and near-cash transfers is performed using estimates of public spending on those items in the OECD Social Expenditures database rather than the NIPA.) Except for the United States, I was not able to find NIPA estimates of the flow of rental services from owner-occupied homes. I therefore included LIS and Census Bureau estimates of these flows without any adjustment when calculating a household's total capital income. Thus, except for rental incomes on owner-occupied homes, capital and labor incomes reported in LIS are adjusted to bring the implied aggregate totals up to corresponding estimates in a country's NIPA, and transfer incomes are adjusted to bring total income amounts up to totals in the OECD Social Expenditure database.

The plausibility of these adjustments depends on the assumption that the aggregate incomes reported in the NIPA or the OECD database are more accurate than those reflected in the unadjusted LIS survey files. The adjustment to LIS incomes will be valid to the extent that income under-reporting in the household data files is proportionately the same, separately for each type of income, across all age groups. If under-reporting of a particular income item represents a more severe problem for aged households, the adjustment will produce an understatement of the relative incomes of the aged. 


\section{The age distribution of factor income and transfers}

Figures 3 and 4 show the age distribution of factor income and transfer income in the four countries, using the average factor income received by 45-49 year-olds as a benchmark for comparison. The tabulations reflect LIS income reports after adjustments to reflect the total incomes recorded in the NIPA or the OECD Social Expenditures database. Readers interested in comparing these estimates with unadjusted estimates based solely on LIS income reports are referred to my earlier study (Burtless 2005). On the whole, the NIPA adjustments have little effect on our interpretation of cross-national differences in the age profile of factor incomes. Average incomes are shown for people in five-year age groups starting at age 15. Children under 15 receive virtually no capital or labor income, although they are beneficiaries under a number of government transfer programs. The only government benefits that can be definitively assigned to child recipients are public transfers for health (see Figure 1). Other transfer benefits are assigned to adult members of a household, though in some cases the adults would be ineligible to receive the benefits if no child dependent were present.

The age profile of factor income is broadly similar in all four countries. Factor income reaches a life-cycle peak shortly before age 45 in Finland, between ages 45-49 in Germany, and at a slightly older age in Britain and the United States. The age profile shows a characteristic pattern of steep increase between age 15 and early middle age, a leveling out or small increase between the late 30 s and early 50s, and then a steep decline after age 55. Nearly all of the decline after age 50 is traceable to a fall in labor earnings. Note that the profiles displayed in Figure 3 reflect only the factor incomes actually earned by adults at successive years of age. Because of income sharing among relatives, the estimates do not necessarily reflect the actual incomes available to pay for consumption in any age group. Young adults earn very little factor income, since many of them are enrolled in school or have just begun to earn wages for the first time. Part or all of their consumption may be financed from the factor incomes received by parents or other middle-aged relatives. Inter-family transfers may also be important to some adults past the age of 65 .

The total factor income at each age can be divided between labor and capital income (see Figure 5). The dark portion of each bar represents the gross labor income received at each age; the light portion represents capital income. A comparison of the age profiles of labor income shows that wage and self-employment income falls off more gradually after age 60 in the United 
States than it does in the other three countries. Americans rely more heavily on labor income in old age than citizens of other industrialized countries. For example, Americans between 65 and 69 earn labor incomes that are about 20 percent of the average factor income received by Americans who are between 45 and 49 years old. The comparable percentage in Britain, Finland, and Germany is between 4 and 6 percent. Even between ages 75 and 79 Americans earn labor incomes that are equivalent to 6 percent of the average factor income of 45-49 yearolds, whereas the comparable percentage in Britain, Finland, and Germany is only about 1 percent. This means that U.S. labor income is somewhat less sensitive to shifts in the old-age dependency ratio than earned income in other rich countries.

The lighter portion of each bar in Figure 5 represents income derived from capital income sources - interest, dividends, rent, funded pension payments, and imputed rent on owneroccupied homes. Unlike labor income, capital income continues to rise through ages 70 or 75 . Capital income is relatively more important for older adults in Britain and the United States than it is in Finland or Germany. In the United Kingdom and the United States the average capital income of people past 65 is more than half again greater than capital income received by adults between 45 and 49. Capital incomes received by the aged in Finland and Germany are relatively much smaller. One implication of this comparison should be obvious. If the future age distribution of capital income remains similar to the distribution observed in 2000, the trend toward an older population will boost capital income more in the United Kingdom and the United States than in Finland or Germany.

Figure 3 provides a four-country summary of the age profile of total factor income. The chart shows sizeable inter-country differences in the profile of factor incomes, especially past age 55. U.K. and U.S. residents receive significantly higher factor incomes than residents of Finland and Germany once they reach late middle age. According to income reports in the LIS files, the total factor income received by 70-74 year-olds represents 38 percent of the average factor income of an American between ages 45 and 49. In Germany and Finland the comparable percentages are just 13 percent and 23 percent, respectively. If this age pattern persists over the next half century, Germany and Finland can expect to see a dramatic fall in the availability of factor income as their populations age. The decline in factor income associated with population aging will be more gradual in the United Kingdom and the United States, even if the trend toward an older population is the same in all four countries. 
Pay-as-you-go transfers. The tax burden of supporting paygo transfers depends on the relative generosity of the transfer system as well as the age distribution of factor incomes. In equation 4 the age profile of transfer generosity, $\beta_{1}, \beta_{2}, \beta_{3}, \ldots, \beta_{N}$, measures average benefit payments received by an age group, $i$, relative to the average factor income received by a middle-aged person, here assumed to be someone between ages 45 and 49. My estimates of $\beta_{i}$ in Figure 4 imply that Finnish transfers are uniformly the most generous up through age 80, at least when generosity is measured relative to the average factor income received by $45-49$ yearold adults. At older ages German and U.K. transfers are relatively more generous, primarily because of the continuing rise in paygo transfers through the public health insurance system (see Figure 1). Interestingly, at ages between 15 and 54 British transfers are relatively more generous than those provided by Germany or the United States. By age 60-64 U.K. transfers are significantly less generous than the benefits provided by the other two European countries. Transfers in the United States are notably less generous for working-age adults than they are in the three European countries, but the relative generosity of the U.S. system rises at age 65, when nearly all Americans become entitled to Medicare benefits and moderately generous Social Security old-age benefits. Except at the oldest ages, transfers to America's elderly are more generous than those provided to the elderly in the United Kingdom, though less generous than transfers in Finland or Germany.

Figure 4 shows that Finland and the United Kingdom are the most generous countries in transferring incomes to the young and the middle-aged, but, except at the oldest ages, Britain ranks low in generosity toward the elderly. Both the United States and Germany appear more generous toward their aged populations than Britain. Note, however, that an upward adjustment in cash and near-cash transfer incomes is needed to bring LIS incomes in the United States and Britain up to totals recorded in their NIPA statistics (see bottom row in Table 1). In contrast, transfer incomes are reasonably well reported by Finnish and German respondents in the LIS household surveys. Although the income adjustments have some effects on estimates of the age profile of transfer generosity displayed in Figure 4, a couple of conclusions seem valid regardless of whether adjusted or unadjusted income estimates are used. First, the United States offers less generous benefits than Finland or Germany at every age. This implies that the tax on factor income needed to support transfers will be higher in Finland and Germany than in the United States regardless of the demographic profile of the population. If each country has the same 
population age structure, the tax burden of supporting paygo transfers will be higher in Finland and Germany that it is in the United States, and this will be the true whether the average age of the population is 25,45 , or 65 . Second, the age profile of public transfers is more heavily tilted toward the aged in Germany than it is in Finland, and it is more heavily tilted toward the aged in the United States than in the United Kingdom. British transfers to working-age adults are relatively more generous than are equivalent transfers in the United States, but the increase in benefit generosity after adults attain age 65 is relatively greater in the United States than it is in Britain. These differences in the age pattern of benefit generosity imply that a shift in the age structure toward an older population will cause a proportionately faster increase in the dependency burden in Germany compared with Finland and in the United States compared with the United Kingdom.

\section{The dependency burden of an aging population}

The results in the previous section can be used to derive estimates of the tax on factor income needed to support paygo transfers. The calculations can be performed based on the current population age structure or on the predicted age structure in some future year. As a starting point it is informative to compare tax burdens when countries are assumed to share a common population age structure. This kind of comparison eliminates differences in measured tax burdens caused by fact that the age distribution of the population differs across countries. To perform the required calculations, I computed the unweighted average population age structure of the United Kingdom in 1999 and Finland, Germany, and the United States in 2000 using the population weights reported in the U.S. Census Bureau's International Data Base (2004). Table 2 shows the results of these calculations when estimates of factor and transfer incomes are based on the income reports in the LIS files adjusted to reflect NIPA and OECD Social Expenditures income totals.

The table shows the age distribution of factor income, transfer income, LIS-reported tax payments, and net disposable income when the population is divided into five age groups children (ages 0-15), young adults (ages 15-34), the middle-aged (ages 35-54), the near-aged (ages 55-64), and the elderly (ages 65 and older). (Results for 0-14 year-olds are not reported in the table.) Estimates of average income and tax payments in a particular age group are measured relative to the average factor income received by a middle-aged person, that is, someone between ages 35 and 54. (The average factor income received by people between 35 and 54 is always 
equal to 100, by definition.) The estimates of factor income reported in Table 2 confirm the results displayed in Figures 3 and 5. Aged adults in Britain and the United States receive higher factor incomes than their counterparts in Finland and Germany. The factor income advantage of aged Britons relative to Finns and Germans is entirely due to higher capital income, while that of older Americans is due both to higher capital income and higher labor income. Among nearaged adults, Americans earn significantly higher factor incomes than their counterparts in all three European countries. Most of their income advantage reflects the fact that Americans between 55 and 64 receive much more labor income, mainly because of a higher employment rate. The LIS survey files show that 54 percent of Americans between ages 60 and 64 derive income from working. The comparable employment rates in Finland, Germany, and the United Kingdom are 29 percent, 36 percent, and 31 percent, respectively.

The results in Table 2 also confirm the sizeable role of paygo government transfers as an income source in Finland and Germany compared with the United Kingdom and the United States. Britons older than 54 can expect to receive significantly smaller government transfers than their counterparts in Finland or Germany. Young, middle-aged, and near-aged adults in the United States receive very small transfers, but America's aged fare better. Government transfers to the aged are relatively more costly in the United States than they are in Britain, though less costly than old-age transfers in Finland and Germany.

The LIS data files contain information on the income taxes and social insurance contributions that income recipients pay out of their gross incomes. The average withholdings for income taxes and employee social contributions are reported in Table 2. Bear in mind that these tax payments finance government spending for functions in addition to public transfers, including education, law enforcement, national defense, and interest on the public debt. The LIS tax estimates show, not surprisingly, that tax payments are highest for middle-aged adults and lowest for the aged. In all four countries estimated tax withholdings are considerably higher for young adults than they are for the aged, notwithstanding the fact that the aged receive higher gross incomes than the young. Much of the income received by the elderly consists of lightly taxed transfers, while a much higher percentage of income received by the young is heavily taxed labor income. The LIS information on tax withholdings permits us to calculate average disposable income, that is, gross factor income and government transfers minus tax payments. Average citizens 65 and older receive relatively high disposable incomes in Germany and the 
United States and comparatively low incomes in Britain and Finland. In both Germany and the United States, net disposable income, including publicly financed health benefits, remains substantially unchanged from middle age onwards (Figure 6). Finnish and U.K. disposable incomes fall sharply in late middle age after reaching a peak between ages 35 and 54 . In Britain and the United States, a much larger percentage of disposable income received by the aged and near-aged is derived from factor income, while in Finland and Germany a much larger fraction is received as government transfers. In all four countries the LIS data imply the aged pay very low taxes. The tabulations in Table 2 suggest that average citizens 65 and older receive disposable incomes that are 75 percent to 100 percent of the average disposable incomes received by adults between 35 and 54. In Germany and the United States, the average disposable incomes of the aged are virtually the same as those received by 35-54 year-olds. Indeed, a major surprise of this analysis is that, accounting for the health care consumption paid for with public insurance, aged Germans and Americans receive average disposable incomes that are approximately as high as the incomes received by working-age adults who are near the peak of their careers (Figure 6).

The information about factor income and government transfers can be combined to calculate the tax rate on factor income needed to pay for transfers. When a common population age structure is assumed for the four countries, the implied tax rates are 33 percent in Finland, 27 percent in Germany, 24 percent in the United Kingdom, and 17 percent in the United States (see memo items in Table 2).

To see how these tax rates will be affected by anticipated population aging, we can derive estimates of $\tau$ using forecasts of the future age distribution of national populations. The estimates displayed in Figure 7 are based on population projections of the U.S. Census Bureau (2004). Predicted tax rates are estimated using estimates of $f_{i}$ and $\beta_{i}$ derived from income reports that have been adjusted for income under-reporting. Figure 7 shows predicted tax burdens between 2000 and 2050 based on the Census Bureau's forecasts of the likely age structure of each country. In view of the differences in the four countries' transfer systems, the rank order of national tax rates is hardly surprising. Given the age structures and transfer systems of the four countries, Finland will face the highest tax rate for state-supported transfers, followed by Germany, the United Kingdom, and the United States. There are differences, however, in the rate of growth in taxes over time. In part, these differences arise because population aging is expected to occur faster in some countries than in others (see Figure 8). The 
population age structure of the United States will shift more slowly than the age structure in other countries. This will depress the growth of taxes needed to pay for government transfers. On the other hand, the age profile of transfer payments is more steeply sloped in the United States than it is elsewhere, so the tax rate needed to support transfers will rise proportionately faster given the same increase in the fraction of population age 65 and older. The German population is expected to age faster than the population of Finland, reinforcing the effects of a paygo transfer system that is heavily tilted in favor of Germany's elderly. By the year 2050, the tax-rate difference between Germany and Finland will be proportionately smaller than it was in 2000 .

Tax rate predictions for the four countries are summarized in a different way in Table 3. Two sets of estimated tax rates are displayed for each country. The rates listed in the columns labeled "a" are the paygo tax rates a country would face if its population age structure in each indicated year is the unweighted average age structure of all four countries. That is, each of the countries is assumed to have an identical age structure in future years, where the age structure in a given year is the unweighted average of the population age profile for that year predicted by the U.S. Census Bureau. The estimates of $\tau$ in column "a" thus eliminate the effects of differential population aging in the four countries and highlight the influence of national differences in the age distribution of factor incomes and the age pattern of transfer payment generosity. The results in column "a" show plainly the importance of cross-national differences in the age distribution of factor incomes and transfer benefits. Finland and Germany face higher taxes to support paygo transfers than Britain or the United States. Because the age pattern of benefit generosity is more heavily tilted towards the aged in Germany and the United States, the tax rate rises proportionately faster in those countries than it does in the other two.

The rates listed in columns labeled " $b$ " are the tax rates countries will face given the national population age structure predicted by the Census Bureau for the indicated year. By comparing the tax rates in the "a" columns for the four countries, we can see which countries have the most burdensome transfer systems and which have an age distribution of factor incomes and paygo transfers that is particularly sensitive to population aging. As should be obvious from the discussion so far, Finland and German have the most burdensome benefit systems, but Germany and the United States have a combination of $f_{i}$ and $\beta_{i}$ that makes their tax burdens more highly sensitive to increases in the average population age. Assuming a common age 
structure and common trend toward population aging, $\tau$ would rise 39 percent in the United Kingdom and 40 percent in Finland between 2000 and 2050, but it would increase 49 percent in Germany and 51 percent in the United States. The faster increase in taxes in Germany and the United States is mainly the result of a public transfer system that is more heavily tilted toward the aged. That is, the gap between transfer benefits received by the aged, on the one hand, and the non-aged on the other, is proportionately bigger in Germany and the United States than it is in Finland or the United Kingdom. The tilt in the U.S. benefit structure is large enough to offset an age profile of factor income that is also unusually tilted in favor of the aged. Compared with their counterparts in the other three countries, Americans older than 55 receive exceptionally large factor incomes. This means factor income will fall more gradually in the United States than in Finland or the United Kingdom when the population grows older. Nonetheless, the tax needed to support paygo transfers will rise proportionately faster in the United States than in either Finland or Britain.

The Table 3 entries under columns labeled " $b$ " show the trend in tax rates required to support paygo transfers based on each country's predicted population change. In spite of a paygo benefit structure that is tilted toward the aged, the United States is predicted to see only a moderate proportional rise in tax burdens. Between 2000 and 2050, $\tau$ will rise just 44 percent in the United States compared with 45 percent in Finland and 57 percent in Germany. The reason for the faster rise in Finnish tax rates is the faster aging of Finland's population compared with that of the United States. The German tax rate will rise faster than the U.S. rate because of faster population aging and because the age distribution of factor incomes and transfer benefits in Germany makes the tax rate about equally sensitive to a shift in the population age structure.

\section{Conclusion}

While all industrial countries will grow older over the next half century, the burden of providing public support to their aging populations will not rise by the same fraction. One reason is that their populations will grow older at different rates. Countries with comparatively high fertility and immigration, such as the United States, will see a slower shift in the age structure compared with countries where fertility rates are lower and immigration is less common. Even ignoring the effect of differences in the pace of population aging, industrial countries would experience widely varying burdens as a result of population aging. This paper has highlighted the role of differences in the age structure of factor incomes and of transfer 
payment generosity in determining the future burden of public support for the aged. The elderly and near-elderly in some countries earn comfortable incomes from their own labor and investments. In other countries the aged receive much smaller factor incomes, and they depend more heavily on transfer payments from the government. The age profiles of factor income and of transfer payment generosity taken in combination determine the taxes that citizens must pay out of their capital and labor incomes to support transfer recipients.

Using income reports in the LIS files in combination with health spending profiles from other sources it is straightforward to measure the age profiles of factor incomes and paygo benefit payments in a number of industrialized countries. These estimates can be matched up to aggregate incomes reported in national income and product accounts to verify the plausibility of the income reports obtained in household surveys. The conclusions drawn in this paper are broadly consistent whether we use uncorrected micro-census income reports or reports adjusted to reflect income under-reporting in the LIS files. A couple of conclusions are unsurprising. Generous social welfare states in continental Europe offer more costly and burdensome paygo transfers to their aged citizens than comparable benefits provided by the United Kingdom or the United States. The generous package of benefits offered in continental Europe will require heavier taxes on factor incomes than are needed in the English-speaking countries regardless of the age structure of the national population. At the same time, factor incomes in continental Europe tend to fall off much more rapidly in late middle age than is the case in either Britain or the United States, in part because labor incomes decline faster after age 55 than they do in the United States and in part because capital incomes are significantly smaller than they are in either Britain or the United States. This pattern of factor income payments will mean that the future availability of factor income will fall off faster in Continental Europe than in the Englishspeaking countries as the population grows older.

The estimates reported in this paper show, however, that population aging will have a relatively bigger impact in countries where the age profile of benefits is more heavily tilted in favor of the elderly. Countries with relatively low overall generosity in social welfare, such as the United States, may nonetheless have benefit systems that are steeply tilted in favor of the aged. High-generosity systems, including the one offered in Finland, may offer public benefits that are less favorably structured in behalf of older citizens. Among the countries considered here, Germany and the United States have social insurance and assistance systems that provide 
relatively generous benefits to the aged and less generous transfers to the non-aged. Even though average paygo transfers rise with a person's age in Finland and the United Kingdom, the schedule of benefits is less steeply sloped than it is in Germany or the United States. If all four countries shared the same age structure and faced an identical increase in average population age, the tax rate needed to support transfers would climb more slowly in Finland and Britain than in Germany or the United States. This result is mainly due to the difference in the age profile of benefits offered by the four countries.

An extension of this study could improve our understanding of future dependency burdens. My estimates of future tax burdens are based on the assumption that the current age profiles of factor incomes and transfer benefits will remain unchanged in the future. Although this assumption provides a sensible starting point for comparing countries and transfer systems, it is not credible in the long run. The estimates in Figure 7 imply that the tax on Finnish factor incomes needed to support paygo transfers could approach 50 percent within the next half century. The actual tax burden to support all state spending would of course be higher than this, because taxpayers also need to pay for public schools, national defense, and other government obligations. The age profile of factor incomes and paygo transfers will probably change long before Finland's tax rates reach the level implied by these calculations. Public pensions will be scaled back or delayed, and workers will be encouraged to accumulate more savings to help pay for their own retirement. Of course, some trends may lift the tax rates needed to support paygo transfers. In a number of countries, including the United States, expenditures on medical care are rising faster than spending on other kinds of household consumption. Since much of this spending, especially by the elderly, is financed out of public budgets, it is possible that the future age profile of transfer benefits will become even more tilted in favor of the aged. By investigating historical evidence about the age distribution of factor incomes and transfer payments, we may gain some understanding of the economic and political determinants of the tax burden. 


\section{References}

Bosworth, Barry P., and Gary Burtless. 2004. "Pension Reform and Saving," National Tax Journal 57(3), September 2004, pp. 703-26.

Burtless, Gary. 2005. "The Age Profile of Income and the Burden of Unfunded Transfers in Four Countries: Evidence from the Luxembourg Income Study," Center for Retirement Research Working Paper 2005-01 (Chestnut Hill, MA: Boston College).

Burtless, Gary, and Sarah Siegel. 2004. "Medical Spending, Health Insurance, and Measurement of American Poverty, " In C. Michael Henry, ed., Race, Poverty and Domestic Policy (New Haven and London: Yale University Press).

Cutler, David M., and Louise M. Sheiner. 2001. "Demographics and Medical Care Spending: Standard and Non-Standard Effects." In Demographic Change and Fiscal Policy, A. Auerbach and R. Lee, eds. (Cambridge: Cambridge University Press).

Economic Policy Committee, European Commission. 2001. Budgetary Challenges Posed by Ageing Populations: The Impact on Public Spending on Pensions, Health and Long-term Care for the Elderly, and Possible Indicators of the Long-term Sustainability of Public Finances. (Brussels: Directorate General for Economic and Financial Affairs of the European Commission).

Keehan, Sean P., Helen C. Lazenby, Mark A. Zezza, and Aaron C. Catlin. 2004. "Age Estimates in the National Health Accounts." Health Care Financing Review. Web Exclusive, Volume 1, Number 1, December 2, 2004. [http://www.cms.hhs.gov/ NationalHealthExpendData/downloads/keehan-age-estimates.pdf]

OECD. 2004a. OECD Health Data 2004. (Paris: OECD). 2004b. OECD Social Expenditure Database, 1980-2001. (Paris: OECD).

Rein, Martin, and Heinz Stapf-Finé. 2001. "Income Packaging and Economic Well-Being at the Last Stage of the Working Career." LIS Working Paper No. 270. Luxembourg: Luxembourg Income Study.

Selden, Thomas M., et al. 2001. "Reconciling Medical Expenditure Estimates from the EPS and the NHA, 1996" Health Care Financing Review. Volume 23, Number 1 (Fall), 161-87.

Sheiner, Louise. 2004. "The Effects of Technology on the Age Distribution of Health Spending: A Cross-Country Perspective." Working Paper. Washington: Board of Governors of the Federal Reserve System.

U.S. Census Bureau. 1993. Money Income of Households, Families, and Persons in the United States: 1992. Current Population Reports, Series P60-184 (Washington, D.C.: U.S. Department of Commerce). 2004. International Data Base. (Washington, D.C.: U.S. Department of Commerce). 
Table 1. Aggregate Incomes Reported in LIS Data Files, in National Income and Product Accounts, and in OECD Social Expenditures Accounts, 1999-2000

\begin{tabular}{|c|c|c|c|c|}
\hline & $\begin{array}{c}\text { Finland } \\
\text { Bil. Euros } \\
(2000) \\
\end{array}$ & $\begin{array}{c}\text { Germany } \\
\text { Bil. Euros } \\
(2000) \\
\end{array}$ & $\begin{array}{c}\text { United } \\
\text { Kingdom } \\
\text { Bil. Pounds } \\
(1999) \\
\end{array}$ & $\begin{array}{c}\text { United } \\
\text { States } \\
\text { Bil. Dollars } \\
(2000) \\
\end{array}$ \\
\hline (1) Gross wage and salary income (LIS) & 49.3 & 905.2 & 396.0 & $4,798.8$ \\
\hline (2) Employee compensation (NIPA) & 62.8 & $1,099.1$ & 495.8 & $5,782.7$ \\
\hline (3) Self-employment income (LIS) & 5.2 & 130.3 & 54.9 & 350.8 \\
\hline (4) Surplus of unincorporated businesses owned by households (NIPA) & 5.3 & 231.4 & 54.2 & 728.4 \\
\hline (5) Income derived from capital, including funded pensions (LIS) & 6.3 & 61.1 & 62.0 & 604.3 \\
\hline (6) Property income, receivable (NIPA) & 7.8 & 309.0 & 119.0 & $1,461.6$ \\
\hline (7) Imputed income from owner-occupied homes (LIS) /a/ & 5.1 & 44.4 & 54.8 & 472.8 \\
\hline (8) Government transfers, except funded pensions and health benefits (LIS) & 19.9 & 315.1 & 109.8 & 558.4 \\
\hline (9) Author's imputation of government-financed health benefits & 6.5 & 153.1 & 52.1 & 566.0 \\
\hline (10) Total transfers & 26.4 & 468.2 & 161.9 & $1,124.4$ \\
\hline (11) Cash and near-cash transfers plus government health benefits (OECD) & 26.5 & 475.1 & 180.5 & $1,323.9$ \\
\hline $\begin{array}{l}\text { Income recorded in or imputed to the analysis file as a percent of external es } \\
\text { (a) Wage and salary compensation: Row (1)/Row (2) }\end{array}$ & 79 & 82 & 80 & 83 \\
\hline (b) Self-employment income: Row (3) / Row (4) & 97 & 56 & 101 & 48 \\
\hline (c ) Capital income: Row (5) / Row (6) & 82 & 20 & 52 & 41 \\
\hline (d) Total factor income: $[\operatorname{Rows}(1)+(3)+(5)+(7)] /[\operatorname{Rows}(2)+(4)+(6)]$ & 87 & 70 & 85 & 78 \\
\hline Government transfers or social benefits: Row (10) / Row (11) & 100 & 99 & 90 & 85 \\
\hline
\end{tabular}

Source: Author's tabulations of LIS data files and OECD and U.S. estimates of national income and products accounts.

/a/ Ignores cost of property taxes. U.K. estimates derived from author's tabulations of 1999 British Household Panel Survey. 
Table 2. Gross and Net Incomes by Age Group in Four Countries: Estimates Based on LIS Income Reports Adjusted to Reflect NIPA and OECD Income Totals

Percent of average factor income received by $35-54$ year-olds

\begin{tabular}{|c|c|c|c|c|c|}
\hline & \multicolumn{5}{|c|}{ Age group } \\
\hline & $15-34$ & $35-54$ & $55-64$ & $65-99$ & $0-99$ \\
\hline \multicolumn{6}{|l|}{ Finland (2000) } \\
\hline Factor income & 50 & 100 & 62 & 14 & 51 \\
\hline of which -- Labor & 48 & 87 & 47 & 2 & 43 \\
\hline Capital & 3 & 13 & 15 & 12 & 8 \\
\hline Transfers, incl. public health benefits & 10 & 13 & 28 & 46 & 17 \\
\hline Taxes & -23 & -45 & -31 & -9 & -24 \\
\hline Net disposable income & 38 & 69 & 60 & 51 & 45 \\
\hline Memo: Implied tax on Finland factor in & for Payg & nsfers & $33.1 \%$ & & \\
\hline \multicolumn{6}{|l|}{ Germany (2000) } \\
\hline Factor income & 41 & 100 & 72 & 23 & 52 \\
\hline of which -- Labor & 38 & 85 & 52 & 3 & 41 \\
\hline Capital & 3 & 15 & 21 & 21 & 10 \\
\hline Transfers, incl. public health benefits & 6 & 9 & 21 & 46 & 14 \\
\hline Taxes & -18 & -41 & -25 & -2 & -20 \\
\hline Net disposable income & 30 & 68 & 68 & 68 & 46 \\
\hline Memo: Implied tax on German factor in & for Payg & nsfers & $27.0 \%$ & & \\
\hline \multicolumn{6}{|l|}{ United Kingdom (1999) } \\
\hline Factor income & 56 & 100 & 70 & 30 & 56 \\
\hline of which -- Labor & 51 & 83 & 40 & 2 & 43 \\
\hline Capital & 4 & 17 & 30 & 28 & 13 \\
\hline Transfers, incl. public health benefits & 9 & 12 & 15 & 37 & 13 \\
\hline Taxes & -22 & -37 & -22 & -5 & -20 \\
\hline Net disposable income & 42 & 74 & 63 & 62 & 50 \\
\hline Memo: Implied tax on U.K. factor inco & Paygo t & ers & $24.1 \%$ & & \\
\hline \multicolumn{6}{|l|}{ United States (2000) } \\
\hline Factor income & 45 & 100 & 89 & 45 & 58 \\
\hline of which -- Labor & 41 & 83 & 62 & 11 & 44 \\
\hline Capital & 4 & 17 & 28 & 34 & 14 \\
\hline Transfers, incl. public health benefits & 4 & 5 & 11 & 40 & 10 \\
\hline Taxes & -11 & -24 & -21 & -6 & -13 \\
\hline Net disposable income & 38 & 81 & 79 & 79 & 54 \\
\hline Memo: Implied tax on U.S. factor incor & Paygo tr & & $16.9 \%$ & & \\
\hline
\end{tabular}

Source: Author's tabulations of LIS data files and OECD and U.S. estimates of national income and product account data as explained in the text.

Note: Age distribution of population is normalized using average population structure in the four countries. 
Table 3. Effect of Population Aging on Tax Rate, $\tau$, Needed to Finance Paygo Transfers, 2000-2050

\begin{tabular}{|c|c|c|c|c|c|c|c|c|c|}
\hline & \multirow[b]{2}{*}{ Year } & \multicolumn{2}{|c|}{ Finland } & \multicolumn{2}{|c|}{ Germany } & \multicolumn{2}{|c|}{ United Kingdom } & \multicolumn{2}{|c|}{ United States } \\
\hline & & (a) & (b) & (a) & (b) & (a) & (b) & (a) & (b) \\
\hline & 2000 & 33 & 33 & 27 & 28 & 24 & 25 & 17 & 16 \\
\hline & 2010 & 35 & 37 & 29 & 31 & 25 & 25 & 18 & 16 \\
\hline & 2020 & 40 & 43 & 33 & 34 & 28 & 27 & 20 & 19 \\
\hline & 2030 & 44 & 46 & 37 & 40 & 31 & 30 & 23 & 21 \\
\hline & 2040 & 45 & 47 & 39 & 43 & 32 & 31 & 25 & 22 \\
\hline & 2050 & 46 & 48 & 40 & 44 & 33 & 33 & 26 & 23 \\
\hline \multicolumn{10}{|c|}{$\tau$ in 2050 as a percent } \\
\hline & of $\tau$ in 2000 & 140 & 145 & 149 & 157 & 139 & 132 & 151 & 144 \\
\hline
\end{tabular}

Source: Author's tabulations of LIS and NIPA data files as explained in text and population projections of the U.S. Census Bureau.

(a) The predicted age structure is assumed identical for each country and reflects the four-country average age structure.

(b) Estimated $\tau$ is based on the predicted age structure for the indicated country. 
Figure 1. Age Profiles of Public Health Benefits Per Head in Four Countries, 1999-2000

Public health benefits per head as a percent of GDP per capita

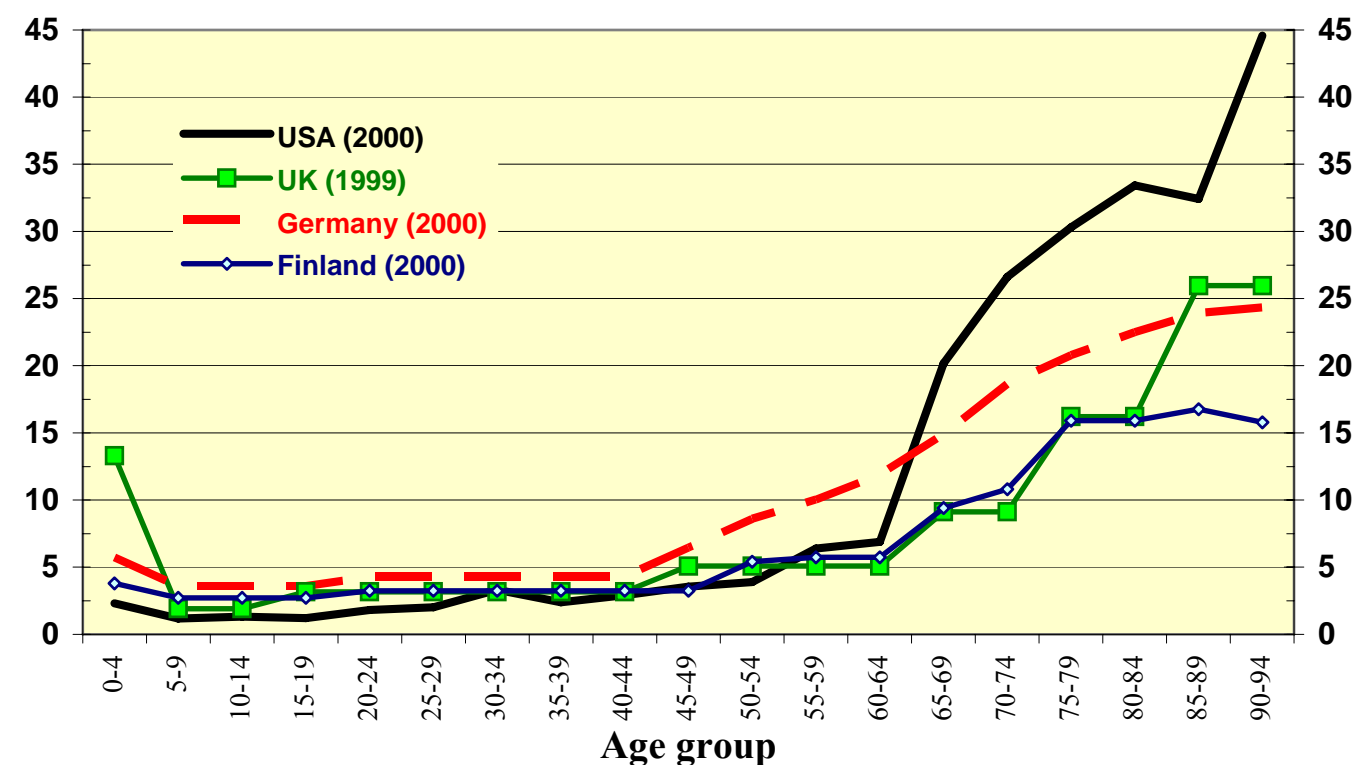

Source: Author's tabulations of 1999-2001 MEPS, Economic Policy Committee-European Commission (2001), and OECD Social Expenditures database (2004) as described in text.

Figure 2. U.S. Public Spending as a Share of Total Spending on Health Goods and Services by Age, 1999-2001

Percent of total health expenditures in age group

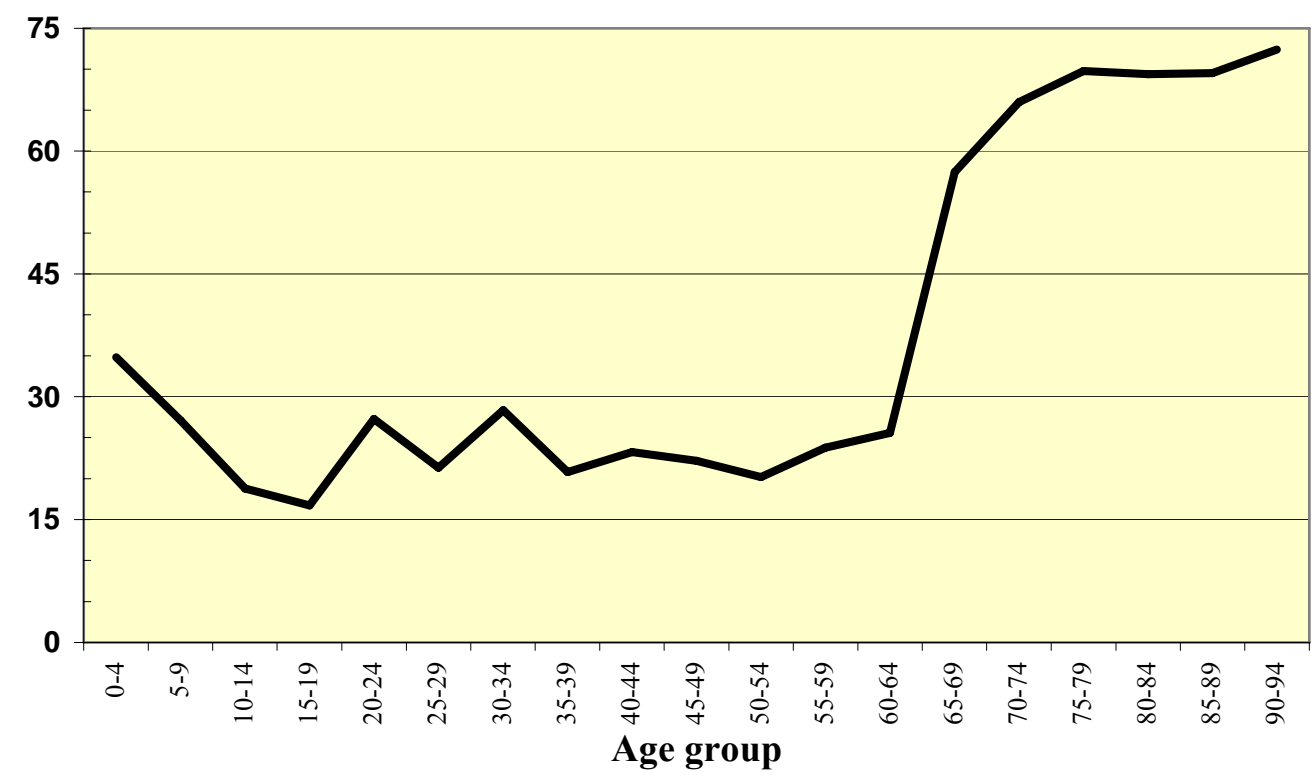

Source: Author's tabulations of 1999-2001 MEPS Household Component Data, Full Year Consolidated Data File. 
Figure 3. Age Profile of Transfer Income in Four Countries with Adjustments to Reflect NIPA Total Income, 1999-2000

Gross Factor Income Received as \% of Average Factor Income Received by 45-49 Year-olds

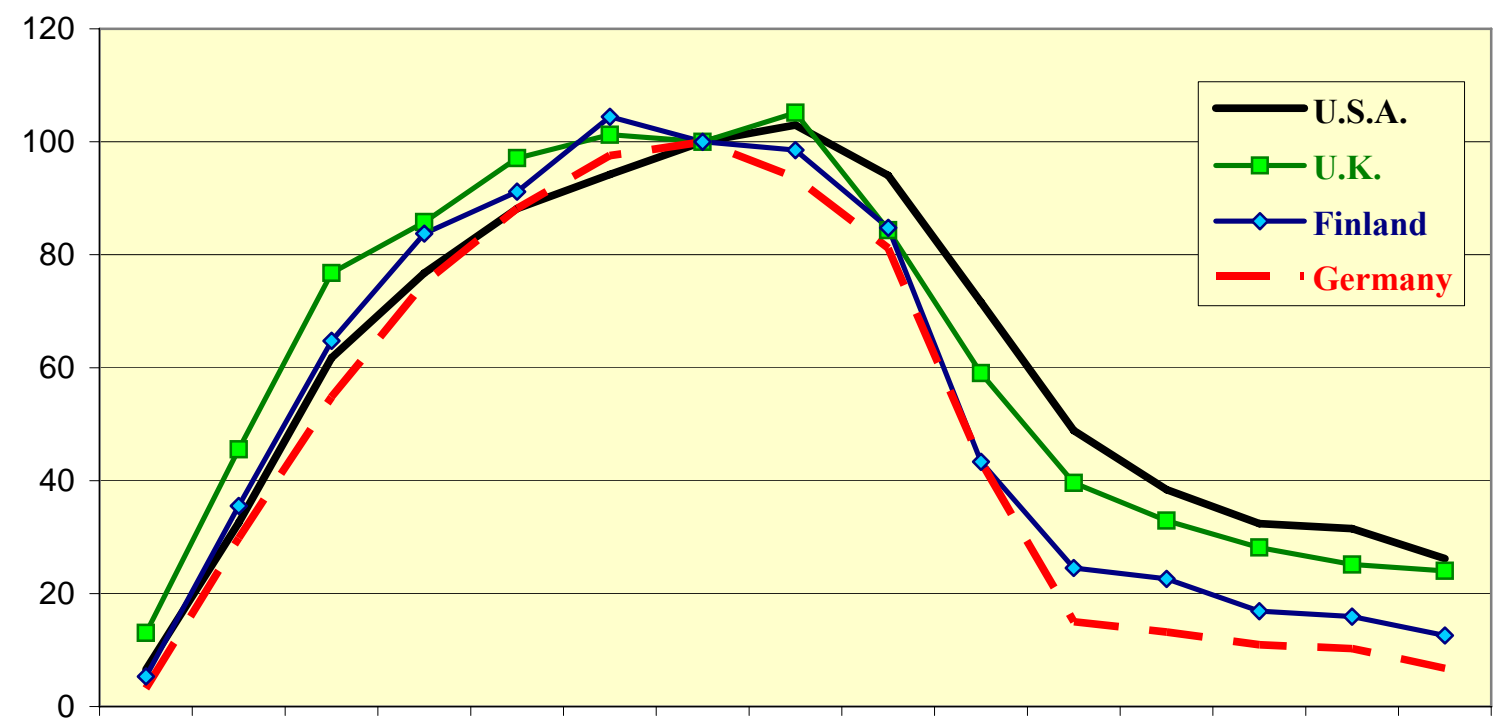

15-19 20-24 25-29 30-34 35-39 40-44 45-49 50-54 55-59 60-64 $65-69$ 70-74 $75-79 \quad 80-84 \quad 85-89$

Age group

Figure 4. Age Profiles of Factor Income in Four Countries with and without Adjustments to Reflect NIPA Total Income, 1999-2000

Transfers Received Measured as \% of

Average Factor Income Received by 45-49 year-olds

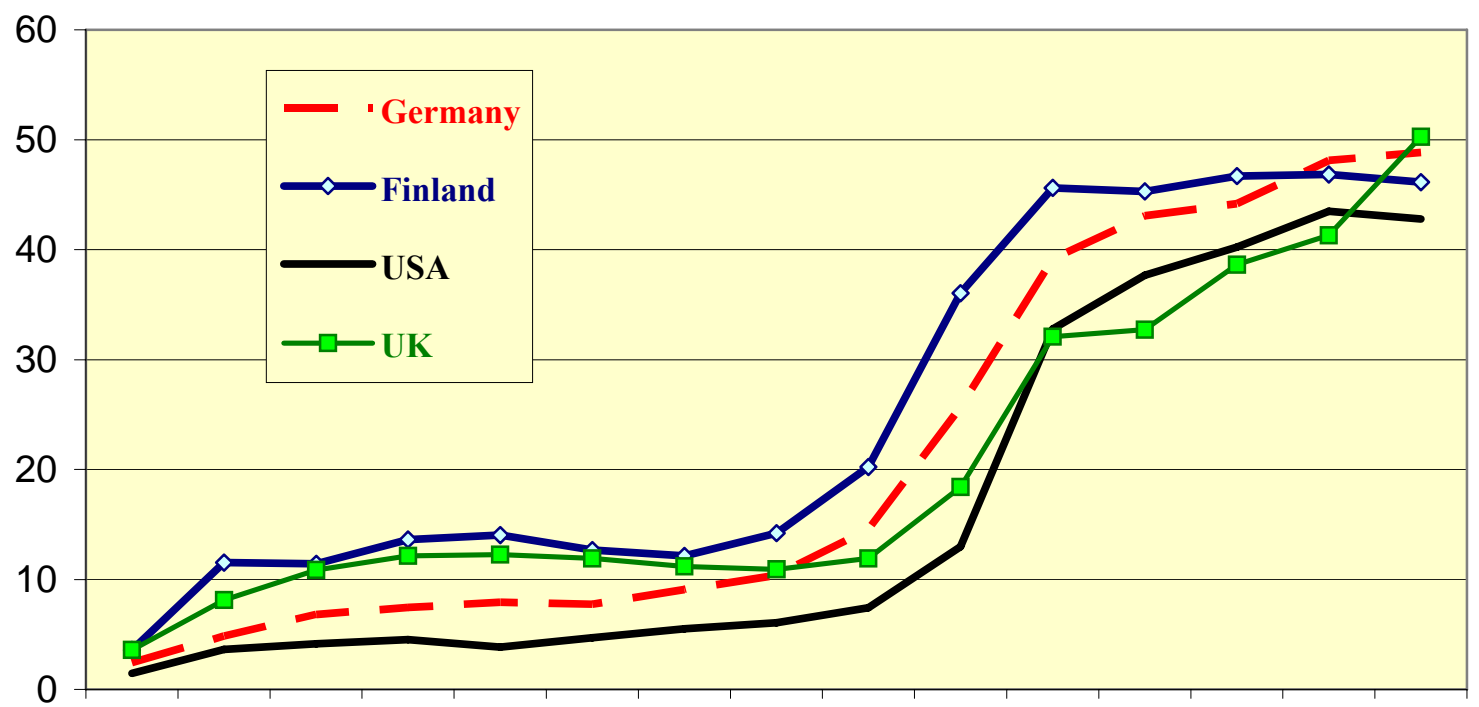

15-19 20-24 25-29 30-34 35-39 40-44 45-49 50-54 55-59 60-64 $65-69 \quad 70-74 \quad 75-79 \quad 80-84 \quad 85-89$ Age group

Source: Author's tabulations of LIS, NIPA, and OECD Social Expenditure data files as explained in text. 
Figure 5. Age Pattern of Factor Income in Four Countries, 1999-2000

Factor income received by average 45-49 year-old $=100$

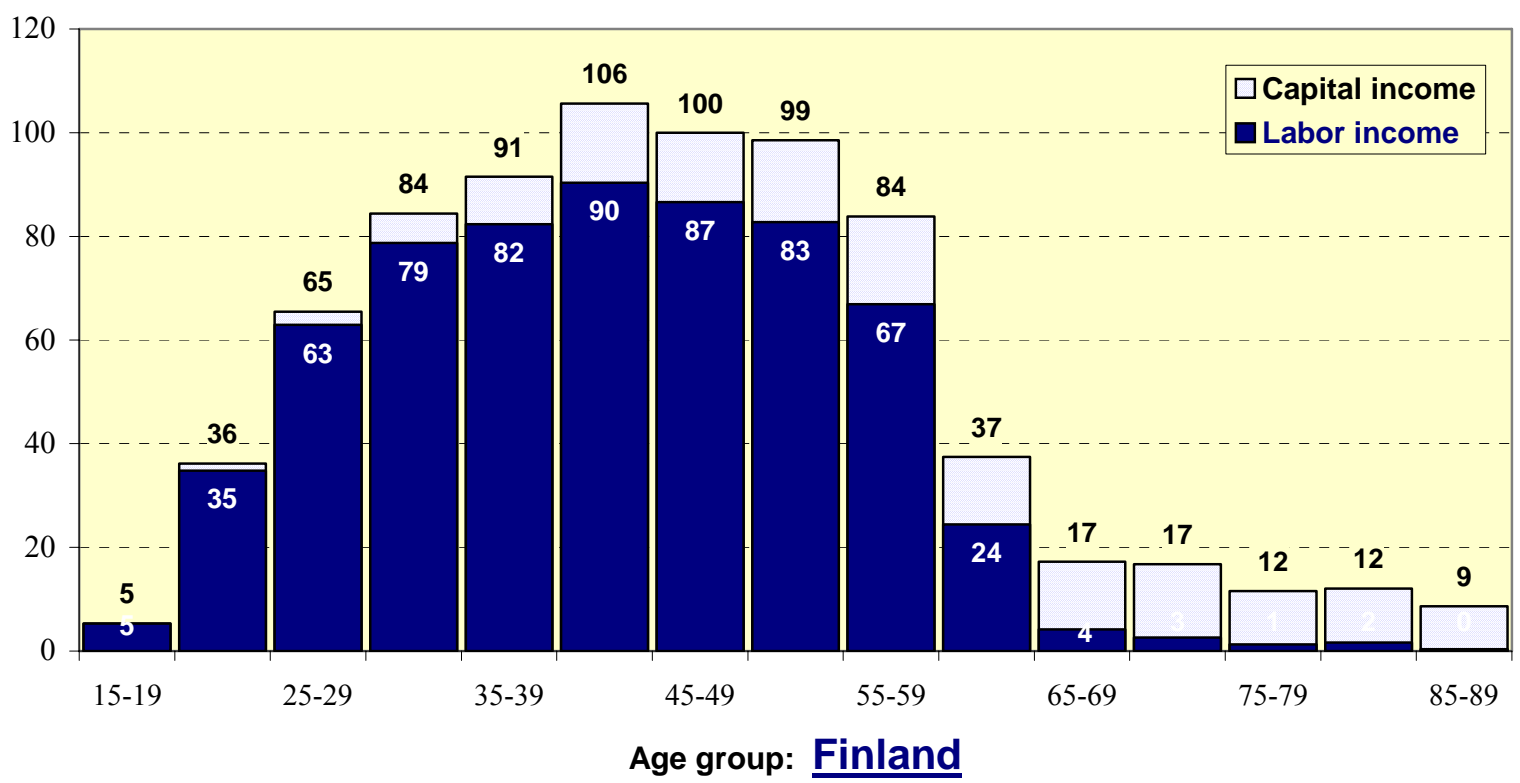

Factor income received by average $45-49$ year-old $=100$

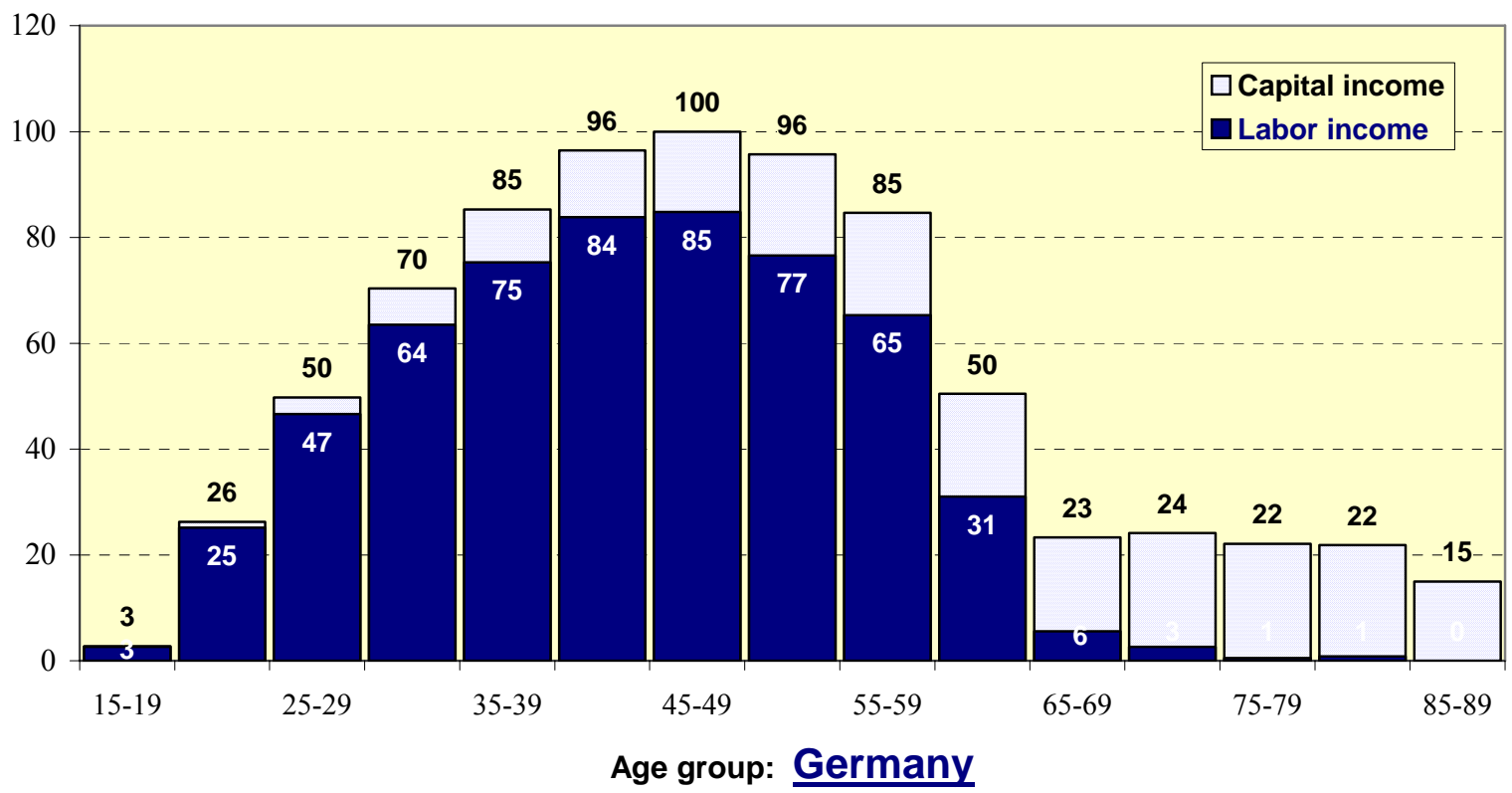

Source: Author's tabulations of NIPA-adjusted LIS data files as explained in text. 
Figure 5. Age Pattern of Factor Income in Four Countries (continued)

Factor income received by average $45-49$ year-old $=100$

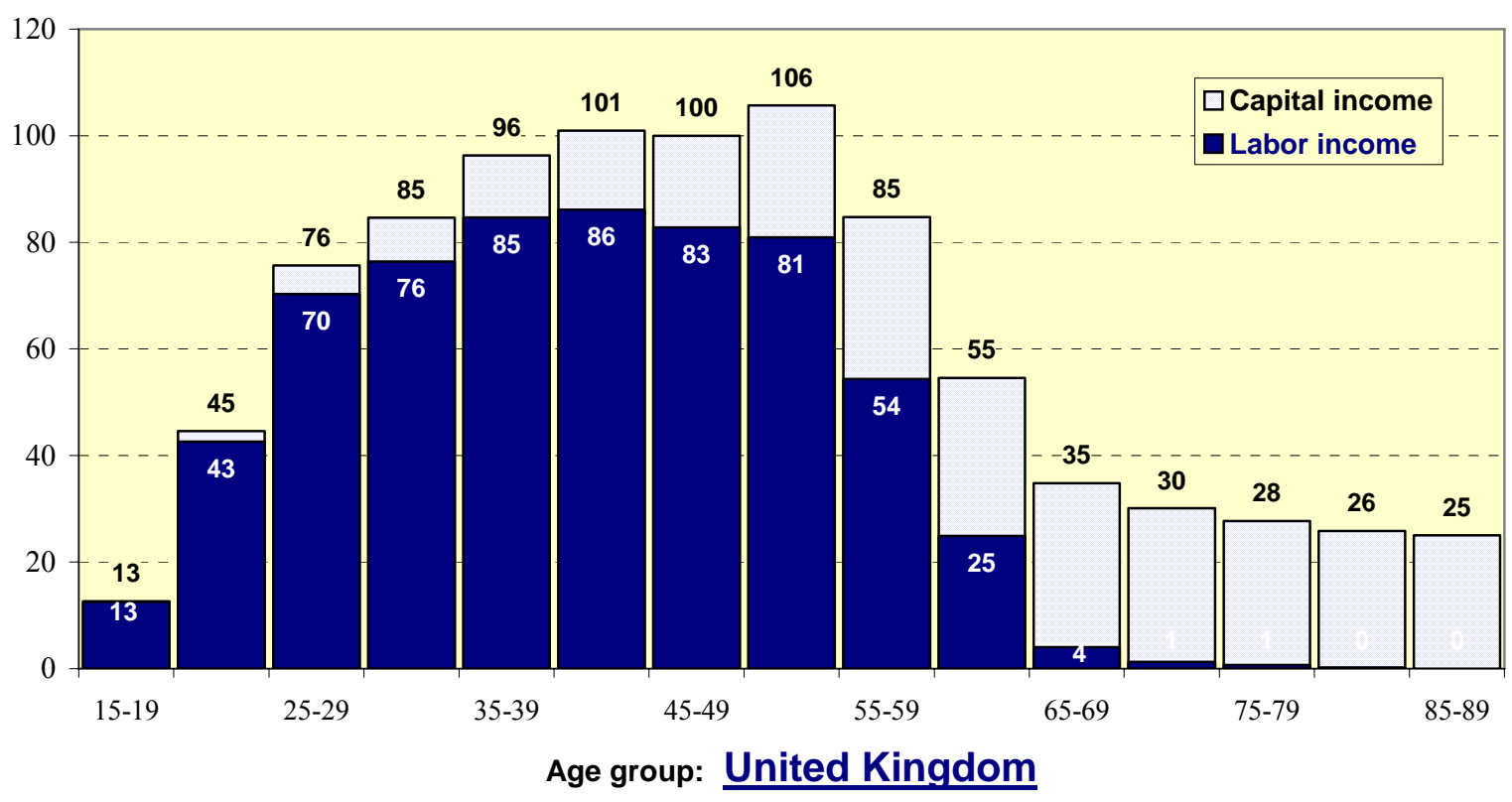

Factor income received by average 45-49 year-old $=100$

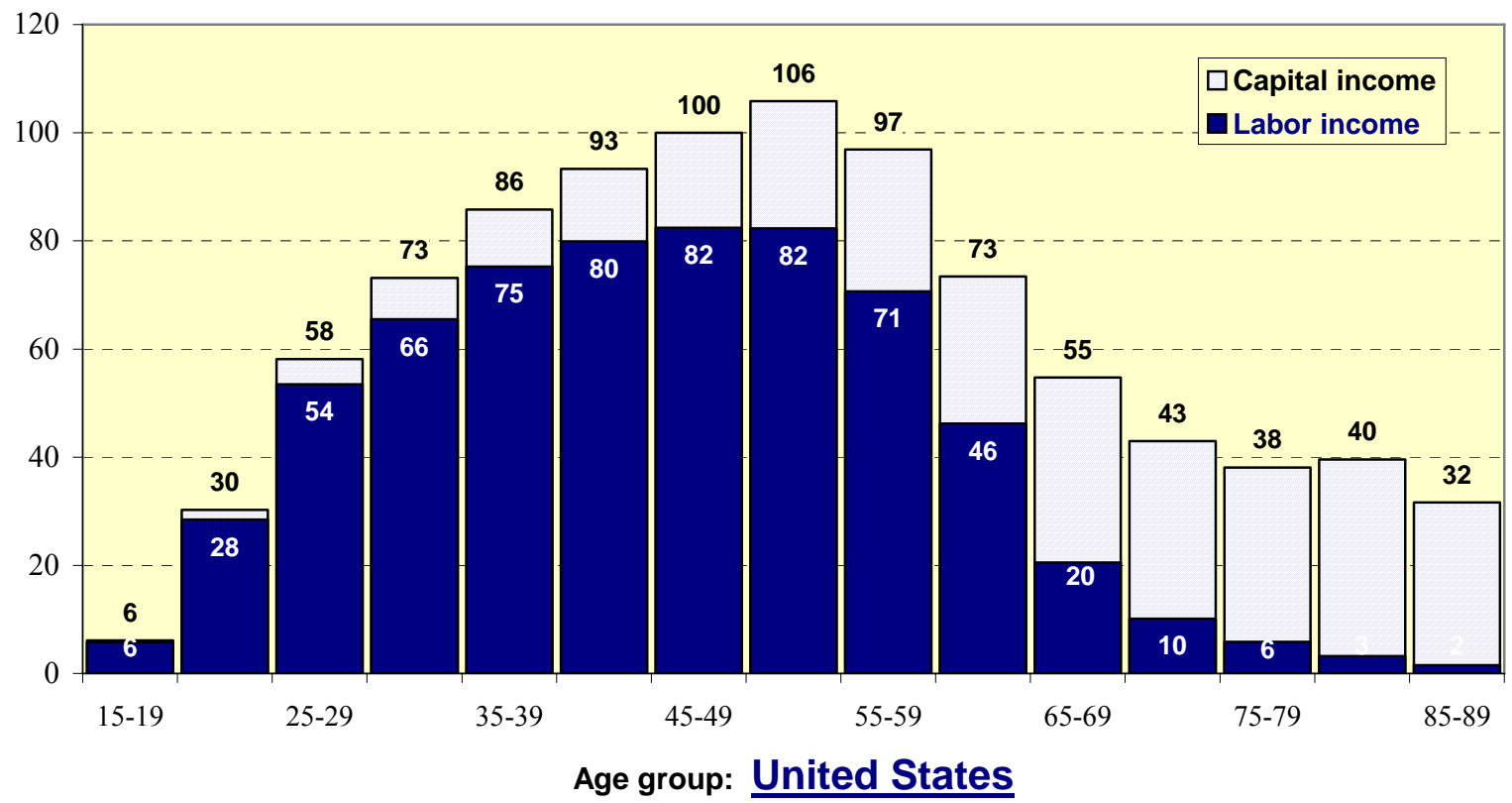

Source: Author's tabulations of NIPA-adjusted LIS data files as explained in text. 
Figure 6. Age Pattern of Disposable Income in Four Countries, 1999-2000

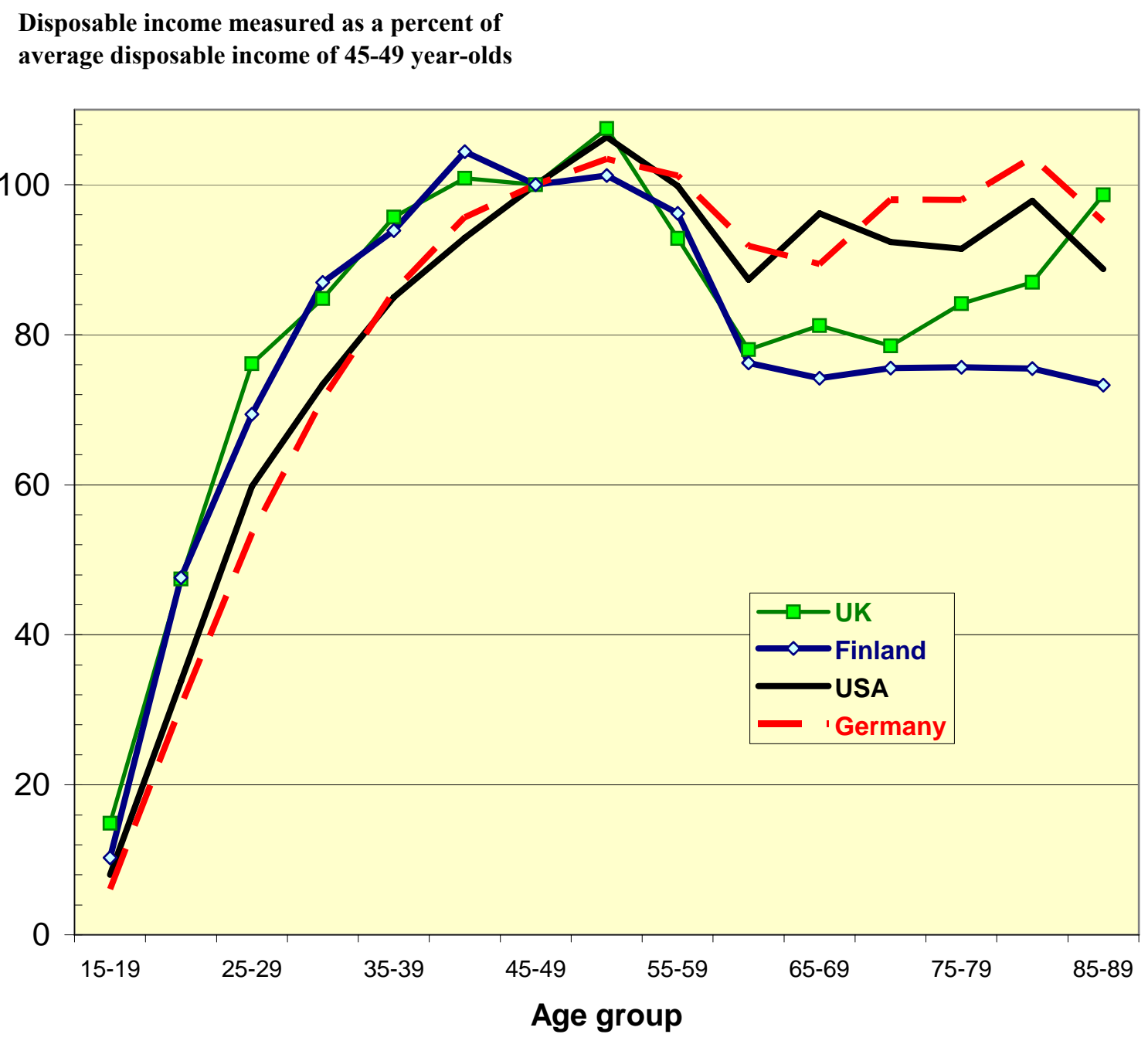

Source: Author's tabulations of LIS, NIPA, and OECD Social Expenditure data files as explained in text. 
Figure 7. Implied Tax on Factor Income Needed to Finance Paygo

Transfers, 2000-2050

Percent of factor income

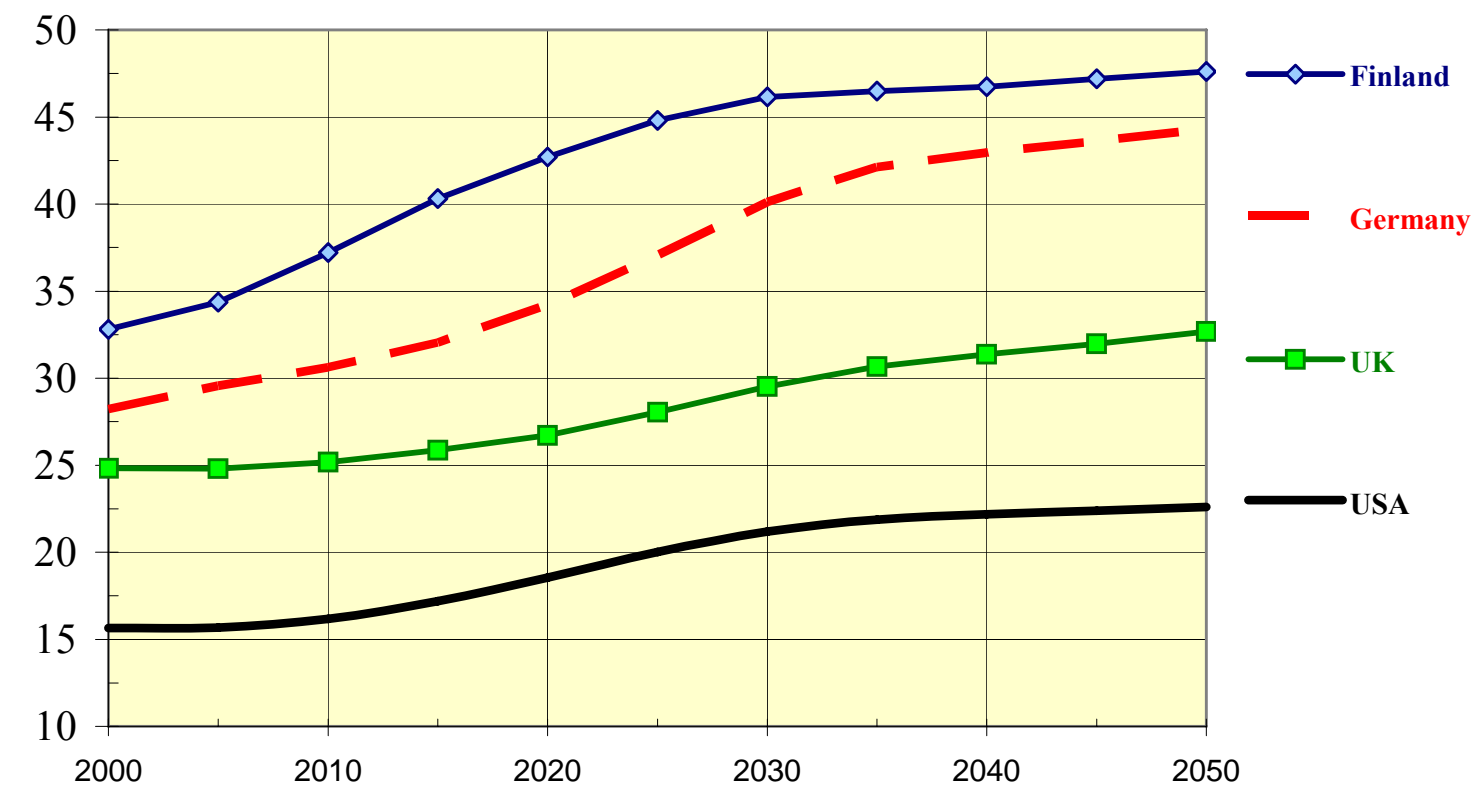

Source: Author's tabulations of LIS, NIPA, and OECD Social Expenditure data files as explained in text. Predictions of the population age structure are derived from U.S. Census Bureau International Data Base (2004).

Figure 8. Old-age Dependency Ratio, 2000-2050

Persons 65 and older per 100 persons age 15-64

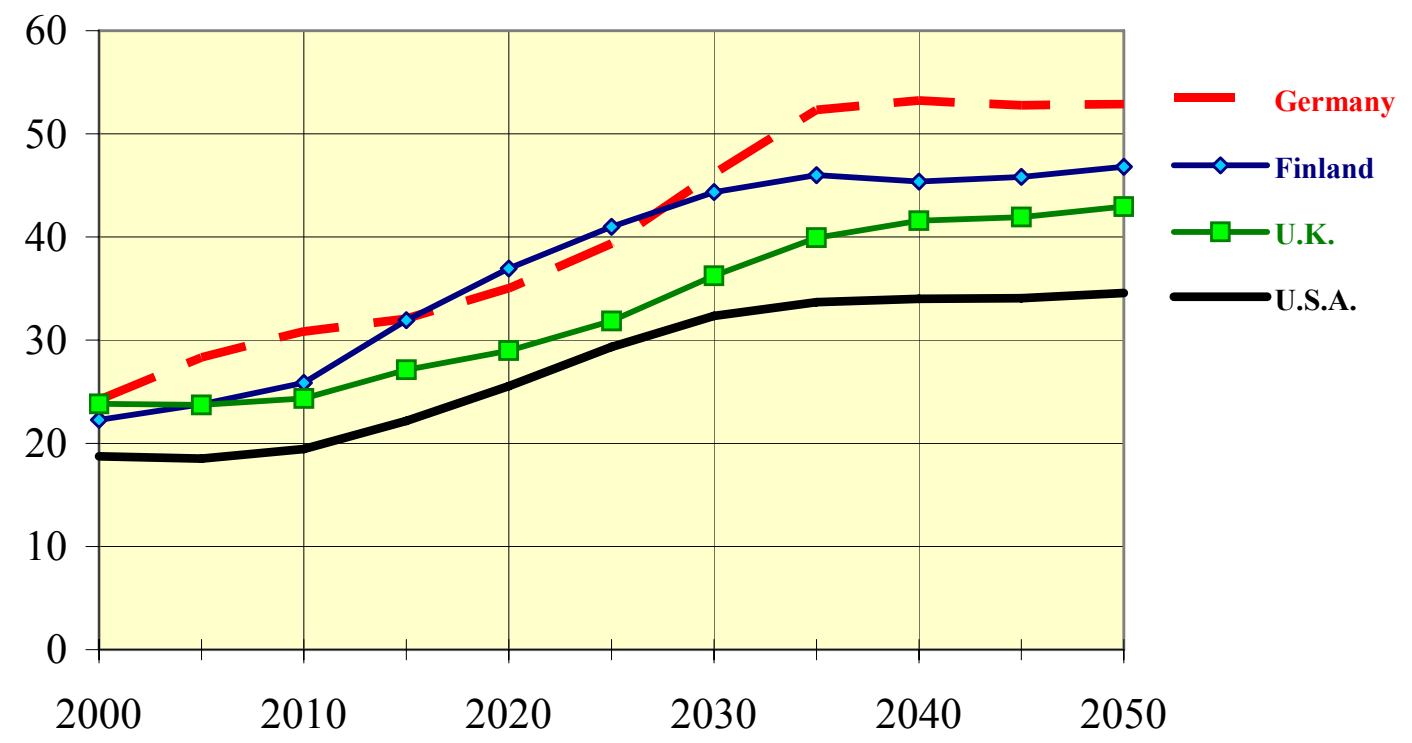

Source: Author's tabulations of U.S. Census Bureau population projections. 


\section{RECENT WORKING PAPERS FROM THE \\ CENTER For RETIREMENT ReSEARCH AT Boston COLlEge}

Population Aging and the Structure of Wages

Bob Triest, Steven Sass and Margarita Sapozhnikov, February 2006

Financing Disability Benefits in a System of Individual Accounts: Lessons from International Experience

Patrick Wiese, February 2006

Long-Term Immigration Projection Methods : Current Practice and How to Improve it

Neil Howe and Richard Jackson, February 2006

Policies to Promote Labor Force Participation of Older Workers

Alicia H. Munnell, January 2006

Private Transfers in a Cross Section of Developing Countries

Donald Cox, Emanuela Galasso and Emmanuel Jimenez, January 2006

Making Maximum Use of Tax-Deferred Retirement Accounts

Janette Kawachi, Karen Smith and Eric Toder, January 2006

When the Nest Egg Cracks: Financial Consequences of Health Problems, Marital Status Changes, and Job Layoffs at Older Ages.

Richard W. Johnson, Gordon B.T. Mermin and Cori E. Uccello, December 2005

How Portfolios Evolve after Retirement: the Effect of Health Shocks.

Courtney Coile and Kevin Milligan, December 2005

Demographic Interactions between North and South and the Implications for North-South Capital Flows

Ralph C. Bryant, December 2005

The Decline in Household Savings: What can we learn from Survey Data?

Barry Bosworth and Lisa Bell, December 2005

The Retirement Consumption Conundrum: Evidence from a Consumption Survey Jonathan Fisher, David S. Johnson, Joseph Marchand, Timothy M. Smeeding, and Barbara Boyle Torrey, December 2005

All working papers are available on the Center for Retirement Research website (http://www.bc.edu/crr) and can be requested by e-mail (crr@bc.edu) or phone (617-552-1762). 